\title{
Inhibitory effects of retinoic acid metabolism blocking agents (RAMBAs) on the growth of human prostate cancer cells and LNCaP prostate tumour xenografts in SCID mice
}

\author{
CK Huynh ${ }^{1,2}$, AMH Brodie ${ }^{2,3}$ and VCO Njar ${ }^{*, 2,3}$ \\ 'Program in Toxicology, University of Maryland School of Medicine, I 0 South Pine Street, MSTF 7-34F, Baltimore, MD 21 20I-I 559, USA; ${ }^{2}$ Department \\ of Pharmacology and Experimental Therapeutics, University of Maryland School of Medicine, 685 West Baltimore Street, Baltimore, MD 2 I 201 - I 559 , \\ USA; ${ }^{3}$ The University of Maryland Marlene and Stewart Greenebaum Cancer Center, School of Medicine, Baltimore, MD 21201 - I 559, USA
}

\begin{abstract}
In recent studies, we have identified several highly potent all-trans-retinoic acid (ATRA) metabolism blocking agents (RAMBAs). On the basis of previous effects of liarozole (a first-generation RAMBA) on the catabolism of ATRA and on growth of rat Dunning R3227G prostate tumours, we assessed the effects of our novel RAMBAs on human prostate tumour (PCA) cell lines. We examined three different PCA cell lines to determine their capacity to induce P450-mediated oxidation of ATRA. Among the three different cell lines, enhanced catabolism was detected in LNCaP, whereas it was not found in PC-3 and DU- I45. This catabolism was strongly inhibited by our RAMBAs, the most potent being VN/I4-I, VN/50-I, VN/66-I, and VN/69-I with IC 50 values of 6.5, 90.0, 62.5, and $90.0 \mathrm{nM}$, respectively. The RAMBAs inhibited the growth of $L N C a P$ cells with $I_{50}$ values in the $\mu$ M-range. In LNCaP cell proliferation assays, VN/I4-I, VN/50-I, VN/66-I, and VN/69-I also enhanced by 47-, 60-, 70-, and 65-fold, respectively, the ATRA-mediated antiproliferative activity. We then examined the molecular mechanism underlying the growth inhibitory properties of ATRA alone and in combination with RAMBAs. The mechanism appeared to involve the induction of differentiation, cell-cycle arrest, and induction of apoptosis (TUNEL), involving increase in Bad expression and decrease in Bcl-2 expression. Treatment of LNCaP tumours growing in SCID mice with VN/66-I and VN/69-I resulted in modest but statistically significant tumour growth inhibition of 44 and $47 \%$, respectively, while treatment with $\mathrm{VN} / \mathrm{I} 4-\mathrm{I}$ was unexpectedly ineffective. These results suggest that some of our novel RAMBAs may be useful agents for the treatment of prostate cancer.
\end{abstract}

British Journal of Cancer (2006) 94, 513-523. doi:I0.1038/sj.bjc.660297। www.bjcancer.com

Published online 31 January 2006

(c) 2006 Cancer Research UK

Keywords: all-trans-retinoic acid (ATRA); catabolism; CYP26; inhibitors; RAMBAs; azolyl retinoids

Retinoids, including vitamin $\mathrm{A}$ and its natural and synthetic analogues, have been used as experimental treatments in cancer patients for the last 30 years (Smith et al, 1992a; Sporn et al, 1994; Lotan, 1996). Retinoic acids play a role in proliferation, differentiation, metabolism, reproduction, and morphogenesis (De Luca et al, 1995; Miller, 1998). Additionally, one such natural analogue, alltrans-retinoic acid (ATRA), has been used successfully in the treatment of acute promyelocytic leukemia (APL) (Huang et al, 1988; Smith et al, 1992b). ATRA acts by binding to nuclear retinoic acid receptors (RARs), of which there are three subtypes, RAR- $\alpha$, $\beta$, and $-\gamma$. (Chambon et al, 1991; Mangelsdorf et al, 1994).

There are numerous evidence for the role of the retinoids, including ATRA, in prostate cancer (PCA). Human, animal, and epidemiological studies suggest that retinoid deficiency plays a role in PCA development (Lasnitzki and Goodman, 1974; Hayes et al, 1988; Carter et al, 1990; Reichman et al, 1990; Hanchette and

*Correspondence: Dr VCO Njar; E-mail: vnjar00 I@umaryland.edu Revised 3 January 2006; accepted 5 January 2006; published online 31 January 2006
Schwartz, 1992; Peehl et al, 1993). Pasquali et al demonstrated that levels of endogenous ATRA are five to eight times lower in human PCA tissues than in normal prostate tissues (Pasquali et al, 1996). Nagy et al (1996) demonstrated that the expression of Bcl-2, an antiapoptotic protein, was regulated by ATRA. Expression of Bcl-2 is also associated with the development of androgen resistance and invasiveness of androgen-independent PCA (McDonnell et al, 1992; Raffo et al, 1995; McDonnell et al, 1997). In addition, other groups have demonstrated the role of ATRA and its synthetic derivatives on growth of both the prostate gland and PCA cell lines (Pollard and Luckert, 1991; Pienta et al, 1993; Young et al, 1994; Gao et al, 1999).

However, the therapeutic effects of the retinoids are limited owing to their rapid in vivo metabolism (Muindi et al, 1992). The first step in the metabolism of ATRA is catalysed by CYP26A1, a cytochrome $\mathrm{P} 450$ enzyme, where the $\mathrm{C}-4$ of ATRA is hydroxylated to 4-hydroxy-ATRA, which can then be oxidized to 4-oxo-ATRA, which undergoes further reactions to yield more polar metabolites (Frolik et al, 1979). CYP26 family appears to be the most dedicated ATRA 4-hydroxylase (Njar, 2002, 2006; Marill et al, 2003). Other CYPs, including CYP1A1, CYP1A2, CYP2C8, CYP2C9, CYP3A4, 
and CYP3A7 are ATRA 4-hydroxylases and are involved in ATRA metabolism as well, although their specificity for ATRA is low (Njar, 2002, 2006; Marill et al, 2003). PCA cells may develop resistance to ATRA using this mechanism as demonstrated by APL patients who relapse within 3-15 months after first remission with ATRA therapy (Norum, 1993).

Although research to date has concentrated on the use of exogenous retinoids, a potential new approach to the treatment and prevention of cancer is the use of retinoic acid metabolism blocking agents (RAMBAs), which increase levels of retinoic acid within tumour cells by blocking their metabolism (Wouters, 1994; Miller, 1998; Njar, 2002, 2006). Additionally, it has been shown that certain retinoids, including ATRA, are capable of directing neoplastic cells to the normal phenotype of morphological maturation and loss of proliferative capacity, thereby reversing or suppressing developing lesions and preventing cancer invasion (Sporn et al, 1976; Sporn, 1991; Lippman et al, 1994; Moon et al, 1994; Lotan, 1996).

We have designed and synthesized a number of novel RAMBAs to inhibit CYP26 and the other ATRA 4-hydroxylases with the goal of preventing in vivo metabolism and thereby increasing the endogenous levels of ATRA (Njar et al, 2000; Patel et al, 2004). These novel RAMBAs have been described as atypical, owing to their multiple biological activities especially in MCF-7 and T47D human breast cancer cells (Patel et al, 2004). The effects of the RAMBAs (VN/14-1, VN/50-1, VN/66-1, and VN/69-1; Figure 1), alone and in combination with ATRA, on ATRA metabolism, and on PCA cell viability, apoptosis, cell cycle, and differentiation, and on in vivo antitumour studies have been examined. In addition, the molecular mechanisms underlying the biological activities of these agents were also investigated. These studies are the basis of this report.

\section{MATERIALS AND METHODS}

\section{Drug preparations}

We have previously published the syntheses of the RAMBAs used in this study (Patel et al, 2004). All-trans-retinoic acid (ATRA) and the RAMBAs were dissolved in $95 \%$ ethanol and stored at $-20^{\circ} \mathrm{C}$ in the dark. The concentrations ( 1 and $5 \mu \mathrm{M})$ of the various agents (retinoids and RAMBAs) are typical for retinoid cancer cells inhibitory studies (Wu et al, 2001). All chemicals were purchased from Sigma Chemical Co. (St Louis, MO, USA) unless otherwise noted.

\section{Cell culture}

Prostate cancer cell lines, LNCaP, PC3, and DU145, were incubated in the RPMI 1640 medium (Gibco-Invitrogen, Carlsbad, CA, USA) preparation containing 10\% FBS (Hyclone, Logan, UT, USA) and $1 \%$ penicillin - streptomycin solution (Gibco-Invitrogen, Carlsbad,
$\mathrm{CA}, \mathrm{USA})$ at $37^{\circ} \mathrm{C}$ and $5 \% \mathrm{CO}_{2}$. All cells were subcultured weekly. LNCaP cells used in the following studies were performed between passages 7-20.

\section{Preparation of cellular CYP26 microsomes}

The procedure described by Han and Choi (1996) was used. Briefly, LNCaP cells were incubated with $1 \mu \mathrm{m}$ ATRA for $24 \mathrm{~h}$ to induce the CYP26 enzyme. The cells were trypsinised and rinsed with phosphate-buffered saline (PBS) (Life Technologies, Grand Island, NY, USA) by centrifugation for $5 \mathrm{~min}$ at $5000 \times \mathrm{g}$ at room temperature. The cells were resuspended in homogenate buffer $(0.5 \mathrm{M}$ sucrose, $10 \mathrm{~mm}$ Tris- $\mathrm{Cl}$ ( $\mathrm{pH} 7.4), 1 \mathrm{~mm}$ ethylenediamine tetraacetate (EDTA), $1 \mathrm{~mm}$ phenylmethylsulfonylfluoride, $0.1 \mu \mathrm{g} \mathrm{ml}^{-1}$ leupeptin, and $0.04 \mathrm{U} \mathrm{ml}^{-1}$ aprotonin), homogenised, and then centrifuged at $9000 \times \mathrm{g}$ for $10 \mathrm{~min}$ at $4^{\circ} \mathrm{C}$. The supernatant was then centrifuged at $100000 \times \mathrm{g}$ for $45 \mathrm{~min}$ at $4^{\circ} \mathrm{C}$. The pellet was resuspended in storage buffer $(0.25 \mathrm{M}$ sucrose, $10 \mathrm{~mm}$ Tris-Cl ( $\mathrm{pH} 7.4$ ), $1 \mathrm{~mm}$ EDTA, $1 \mathrm{~mm}$ phenylmethylsulfonylfluoride, $0.1 \mu \mathrm{g} \mathrm{ml}^{-1}$ leupeptin, and $0.04 \mathrm{U} \mathrm{ml}^{-1}$ aprotonin) and stored at $-20^{\circ} \mathrm{C}$.

\section{Cellular microsomal CYP26 assay}

The procedure for the hepatic microsomal enzyme assay (for ATRA 4-hydroxylases) was used where $100 \mu$ l of cellular CYP26 microsomes $\left(500 \mu \mathrm{g} \mathrm{ml}^{-1}\right.$ dissolved in storage buffer) was substituted for $100 \mu \mathrm{l}$ of hepatic microsomes. The retinoid products were extracted, processed, and analysed by HPLC as previously described (Patel et al, 2004).

\section{Cellular CYP26 assay}

As modified from a procedure described by Wouters et al (1992), approximately $10^{6} \mathrm{LNCaP}$ cells were incubated with $1 \mu \mathrm{m}$ ATRA for $24 \mathrm{~h}$ to induce the CYP26 enzyme. Following ATRA treatment, the LNCaP cells were incubated with 0.1 or $0.8 \mu \mathrm{M}\left[11,12-{ }^{3} \mathrm{H}\right]-\mathrm{ATRA}$ (PerkinElmer Life and Analytical Sciences, Inc., Boston, MA, USA) for $5 \mathrm{~h}$. Following the $5 \mathrm{~h}$ incubation, the medium was collected and the cells were trypsinised and collected. The retinoid products were extracted, processed, and analysed by HPLC as previously described (Patel et al, 2004).

\section{WST-1 cell viability assay}

To measure cell viability, 24-well plates were coated with a $0.05 \%$ poly-L-lysine solution for $30 \mathrm{~min}$. The wells were then washed with sterilised $\mathrm{dH}_{2} \mathrm{O}$. LNCaP cells $\left(1 \times 10^{4}\right)$ were seeded in the plates and maintained in RPMI 1640 medium (Gibco-Invitrogen, Carlsbad, CA, USA). The cells were allowed to attach for $36 \mathrm{~h}$. After attachment, fresh media was added and the cells were treated with a concentration range of either ATRA or each of the RAMBAs
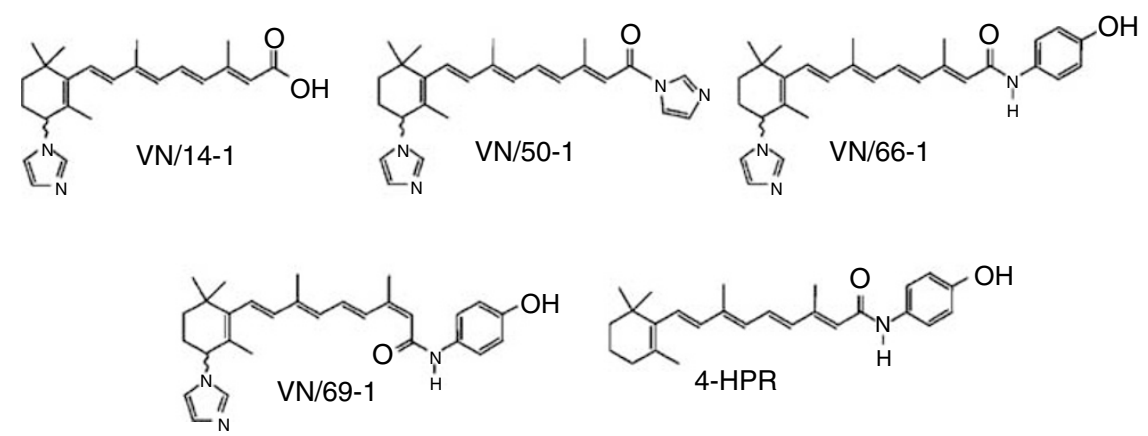

Figure I Chemical structures of RAMBAs, VN/I4-I, VN/50-I, VN/66-I, and VN/69-I and 4-HPR. 
for 6 days. The media was changed every 3 days. On the day the assay was performed, the media was removed and $1 \mathrm{ml}$ of a stock solution of WST-1 (4-[3-(4-iodophenyl)-2-(4-nitrophenyl)2H-5-tetrazolio]-1,3-benzene disulfonate) cell proliferation reagent (Boehringer Mannheim, Indianapolis, IN, USA), diluted 1:10 in RPMI 1640 medium (without FBS), was added to each well. The plates were incubated at $37^{\circ} \mathrm{C}$ for $3 \mathrm{~h}$. The media was then removed and $500 \mu \mathrm{l}$ of DMSO was added and agitated vigorously for $5 \mathrm{~min}$. The slightly red tetrazolium salt WST-1 is reduced to a dark red, water-soluble formazan product by mitochondrial dehydrogenase from living cells, which gives absorbance at a wavelength of $450 \mathrm{~nm}$.

\section{Differentiation assay (Western-blot analysis of cytokeratins $8 / 18$ )}

LNCaP cells were incubated in the RPMI 1640 medium (GibcoInvitrogen, Carlsbad, CA, USA) preparation containing $1 \mu \mathrm{M}$ ATRA alone or in combination with $1 \mu \mathrm{m}$ of each of the RAMBAs for 6 days. LNCaP cells were scraped with $1.5 \mathrm{ml}$ of PBS. The cells were collected by centrifugation, resuspended in ice-cold cell lysis buffer $(0.1 \mathrm{M}$ Tris- $\mathrm{HCl}, 0.5 \%$ Triton X-100, and protease inhibitor cocktail (Boehringer, Indianapolis, IN, USA)), and sonicated. The homogenates were incubated on ice for $30 \mathrm{~min}$, subjected to centrifugation at $13000 \times \mathbf{g}$ for $30 \mathrm{~min}$, and the supernatants were separated and stored at $-80^{\circ} \mathrm{C}$ until use. Protein concentrations were determined by the Bradford method using a Bio-Rad kit (Hercules, CA, USA). A measure of $50 \mu \mathrm{g}$ of cell lysate was subjected to $10 \%$ sodium dodecyl sulfate-polyacrylamide gel electrophoresis (SDSPAGE) using the Mini-PROTEAN3 electrophoresis module assembly (Bio-Rad, Hercules, CA, USA) at $60 \mathrm{~V}$ at room temperature. The separated lysates on 10\% SDS-PAGE gel were transferred onto Hybond ECL nitrocellulose membrane (Amersham, Arlington Heights, IL, USA) overnight at $20 \mathrm{~V}$ at $4^{\circ} \mathrm{C}$. Western-blot analysis was performed on the nitrocellulose membrane. The membrane was blocked for $1 \mathrm{~h}$ in $10 \%$ nonfat dried milk and PBS containing $0.5 \%$ Tween 20 (PBS-T) at room temperature. Following washing in PBS-T, the membrane was incubated with mouse monoclonal IgG antibody to cytokeratin $8 / 18$ or $\beta$-actin (Santa Cruz Biotechnology, Santa Cruz, CA, USA and Oncogene Research Products, Boston, MA, USA, respectively) dissolved in $10 \%$ nonfat dried milk (1:5000 or $1: 10000)$, respectively) for $1 \mathrm{~h}$ at room temperature. Following washing, the membrane was incubated with horseradish peroxidase-linked anti-mouse IgG antibody (Amersham, Arlington Heights, IL, USA and Oncogene Research Products, Boston, MA, USA, respectively) dissolved in $10 \%$ nonfat dried milk $(1: 1000)$ for $1 \mathrm{~h}$ at room temperature. The membrane was incubated in $4 \mathrm{ml}$ ECL Western Blotting Analysis System (Amersham, Arlington Heights, IL, USA) for $1 \mathrm{~min}$ at room temperature. The membrane was resolved on chemiluminescence film (Amersham Hyperfilm High Performance chemiluminescence film, Arlington Heights, IL, USA) and the film was developed using an X-ray developer (M35A X-OMAT Processor, Eastman Kodak Company, Rochester, NY, USA). The intensity of the bands on film was analysed using ImageQuant 5.0 software (Amersham, Arlington Heights, IL, USA). The band intensity corresponds to the level of protein expression of cytokeratin $8 / 18$, which is shown to be expressed in differentiated cells of epithelial origin (Peehl et al, 1993; Hsieh et al, 1995).

\section{Western-blot analysis of Bad and Bcl-2}

The Western-blot protocol described for cytokeratins 8/18 was followed with some exceptions. Cell lysates $(50 \mu \mathrm{g})$ were separated on a $15 \%$ SDS-PAGE gel. All washing was performed using TBS containing $1 \%$ Tween 20 (TBS-T). Blocking was performed using $5 \%$ milk in TBS-T. Incubations were performed using rabbit monoclonal IgG antibody to Bad and Bcl-2 (1:1000), as well as horseradish peroxidase-linked anti-rabbit IgG antibodies $(1: 2000)$ (Cell Signaling Technology, Beverly, MA, USA).

\section{TUNEL (terminal deoxynucleotidyl transferase-mediated dUTP nick end labelling) assay}

A total of $4000 \mathrm{LNCaP}$ cells were plated on each well of an eightwell Lab-Tek II $^{\mathbb{R}}$ chamber slide (Nalge Nunc International, Naperville, IL, USA). The LNCaP cells were then treated with either 1 or $5 \mu \mathrm{M}$ of ATRA or RAMBA for 6 days. Cells were then fixed in $4 \%$ paraformaldehyde solution in $\mathrm{dH}_{2} \mathrm{O}$. The cells were then processed and stained with FITC (fluorescein isothiocyanate) according to kit instructions (In situ cell death detection kit, AP, Roche Diagnostics Corp., Indianapolis, IN, USA). The FITCstained cells are then mounted with VectorShield ${ }^{\circledR}$ mounting medium for fluorescence with DAPI $\left(4^{\prime}, 6\right.$-diamidine- $2^{\prime}$-phenylindole dihydrochloride) nuclear stain (Vector Laboratories, Inc., Burlingame, CA, USA) and covered with ApopTag ${ }^{\circledR}$ plastic coverslips (Intergen Company, Purchase, NY, USA). The slides were then examined under fluorescence microscopy (Eclipse E400, Nikon, Inc., Melville, NY, USA) and counted using SPOT Advance $^{\circledR} 3.5$ software (Diagnostic Instruments, Inc., Sterling Heights, MI, USA).

\section{Cell-cycle analysis}

LNCaP cells were treated with 1 or $5 \mu \mathrm{m}$ of ATRA or each of the RAMBAs for 6 days. The cells were trypsinised and washed twice in PBS (Life Technologies, Grand Island, NY, USA). The cells were fixed by adding $70 \%$ ethanol and stored at $-20^{\circ} \mathrm{C}$ until staining. The cells were washed twice in PBS. A volume of $1 \mathrm{ml}$ of a propidium iodide (PI) solution $\left(50 \mu \mathrm{g} \mathrm{ml}^{-1}\right.$ in PBS) and $500 \mu \mathrm{l}$ of an RNase stock solution $\left(100 \mu \mathrm{g} \mathrm{ml}^{-1}\right)$ were added to the cells and incubated for $1 \mathrm{~h}$ in the dark. Approximately $10^{4}$ stained cells were then analysed by flow cytometry (Becton Dickenson FACScan, Franklin Lakes, NJ, USA). The percentages of cells in $G_{0} / G_{1}, S$, and $\mathrm{G}_{2} / \mathrm{M}$ phases of the cell cycle as well as percentage of apoptotic cells (sub $G_{0} / G_{1}$ ) were determined using MODFIT LT software (Verity Software House, San Jose, CA, USA). The percentages of cells in $G_{0} / G_{1}, S$, and $G_{2} / M$ phases of the cell cycle were obtained from diploid cells in the sample and the percentage of apoptotic cells (sub $G_{0} / G_{1}$ ) was obtained from total cells minus the debris.

\section{In vivo antitumour studies (LNCaP human prostate carcinoma xenograph mice model)}

All animal studies were performed according to the guidelines and approval of the Animal Care Committee of the University of Maryland School of Medicine, and were consistent with United Kingdom Coordinating Committee on Cancer Research guidelines for the welfare of animals in experimental neoplasia. The procedure was modified from Grigoryev et al (1999). Briefly, LNCaP cells were trypsinised, counted, and suspended in Matrigel $\left(2 \times 10^{7}\right.$ cells $\left.\mathrm{ml}^{-1}\right)$ (Fisher Scientific International, Inc., Hampton, $\mathrm{NH}$, USA). Male SCID mice of 4-6 weeks of age were obtained from the National Cancer Institute (Frederick, MD, USA). Each mouse was inoculated s.c. with $0.1 \mathrm{ml}$ of the cell suspension at two sites in the flank. The size of the tumours was determined by measuring the tumour volumes using calipers. Tumour volumes were calculated using the formula $V=4 / 3 \times \pi \times r_{1}^{2} \times r_{2}\left(r_{1}<r_{2}\right)$. The tumours were allowed to develop to approximately $100 \mathrm{~mm}^{3}$ before treatment. The mice were treated with $10 \mathrm{mg} \mathrm{kg}^{-1}$ (which is equivalent to $0.033 \mathrm{mmol} \mathrm{kg}^{-1}$ ) of ATRA or an equivalent dose to $0.033 \mathrm{mmol} \mathrm{kg}{ }^{-1}$ of each RAMBA (VN/14-1, VN/50-1, VN/66-1, and VN/69-1) dissolved in hydroxypropyl- $\beta$-cellulose (HPC, $0.3 \%$ in saline). Tumour volumes were measured twice weekly and weights of animals were taken weekly after the initiation of treatment. The mice were subjected to 6 weeks of treatment. The 
mice were then killed and the tumours were excised, weighed, and stored at $-80^{\circ} \mathrm{C}$ until analysis. Additionally, the plasma was collected with $50 \mathrm{IU}$ of heparin and stored at $-80^{\circ} \mathrm{C}$ until analysis.

\section{Statistical analysis}

One-way analysis of variance (ANOVA) with post test, which was the Bonferroni multiple comparisons test, was performed to compare all pairs of treatment groups using InStat ${ }^{\mathbb{R}} 3$ (GraphPad Software, Inc., San Diego, CA, USA). A $P<0.05$ was considered significant.

\section{RESULTS}

ATRA metabolism is inducible in LNCaP cells but not in PC3 and DU145 cells

To assess the induction of ATRA metabolism in LNCaP, PC-3 and DU145 prostate cells, these cells were pre-incubated with $1 \mu \mathrm{M}$ ATRA for various time points from 4 to $48 \mathrm{~h}$ and then further incubated with $0.8 \mu \mathrm{m}\left[11,12-{ }^{3} \mathrm{H}\right]$-ATRA for $5 \mathrm{~h}$ to measure ATRA metabolism. Our results show that LNCaP cells were induced by ATRA and were able to metabolise $\left[11,12-{ }^{3} \mathrm{H}\right]$-ATRA to more polar products from the 4 to $48 \mathrm{~h}$ time points with maximum metabolism occurring at $36 \mathrm{~h}$ (Figure 2). PC-3 cells did not show any metabolism of $\left[11,12-{ }^{3} \mathrm{H}\right]$-ATRA from these time points (Figure 2) and also up to 9 days (data not shown). DU145 cells were able to metabolise $\left[11,12-{ }^{3} \mathrm{H}\right]$-ATRA from the 4 to $48 \mathrm{~h}$ time points (Figure 2); however, this metabolism was not enhanced despite ATRA treatment. As only the LNCaP cell line was able to metabolise ATRA, it was utilised in subsequent cellular assays.

\section{Inhibition of ATRA metabolism in intact LNCaP cells (cellular assay)}

To assess the ability of our novel RAMBA to inhibit ATRA metabolism in intact cells, we used VN/14-1, VN/50-1, VN/66-1,

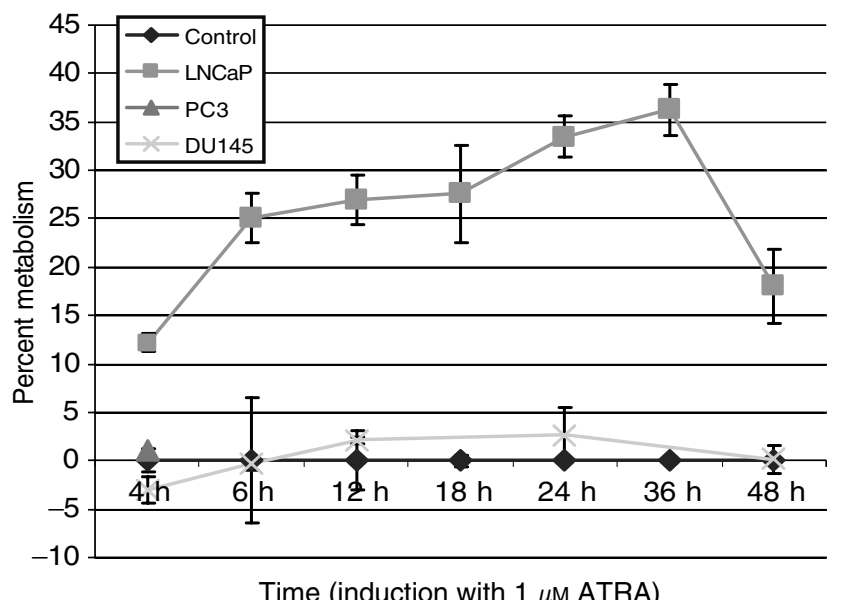

Figure 2 Time course of induction of CYP26 in prostate cancer cells. LNCaP, PC3, and DUI45 cells were pre-incubated with I $\mu \mathrm{M}$ ATRA for various time periods to induce the CYP26 enzyme. Cells were then isolated and incubated at $37^{\circ} \mathrm{C}$ for $5 \mathrm{~h}$ with $0.8 \mu \mathrm{M}\left[11,12-^{3} \mathrm{H}\right]$-ATRA. Retinoids were extracted, and metabolites analysed by HPLC as described in Materials and Methods. Metabolic activity was calculated as percentage of polar ATRA metabolites of total radioactivity. The metabolic activity of induced LNCaP, PC3, and DUI 45 cells was then divided by the metabolic activity of the respective un-induced cells (percent metabolism). The percent metabolism of each un-induced cell line was set to the $x$-axis (Control) and the percent metabolism of the induced cell lines was plotted accordingly. The experiments were performed thrice. and VN/69-1 to evaluate their inhibitory potencies in LNCaP cells. Human LNCaP carcinoma cells cultured under control conditions are unable to metabolise ATRA into more polar metabolites (data not shown). However, after pretreatment with $1 \mu \mathrm{M}$ ATRA for $12-15 \mathrm{~h}$, the cells show extensive ATRA metabolism (Figure 3A), converting ATRA into highly polar metabolites (HPM, retention time, $\left.R_{\mathrm{t}}=3-6 \mathrm{~min}\right)$, and prominent metabolites of medium polarity (MMP, $R_{\mathrm{t}}=8-12 \mathrm{~min}$ ), including 4-oxo and 4-hydroxyATRA. ATRA metabolism is inhibited dose dependently by VN/141 (Figures $3 \mathrm{~B}-\mathrm{D}$ ). Identical results were also obtained with the other three compounds tested. The $\mathrm{IC}_{50}$ values for these compounds were determined from dose-response curves and are presented in Table 1. The compounds inhibited intracellular ATRA metabolism with decreasing activity in the order: VN/14$1>\mathrm{VN} / 66-1>\mathrm{VN} / 50-1=\mathrm{VN} / 69-1$. Compound VN/14-1 was the most active with an $\mathrm{IC}_{50}$ value of $6.5 \pm 1.5 \mathrm{nM}$. VN/50-1 also inhibited ATRA metabolism of microsomes prepared from T47D cells previously exposed to ATRA with an $\mathrm{IC}_{50}$ value of $7.0 \pm 1.2 \mathrm{nM}$, which is of about a 13-fold higher potency compared to the cellular $\mathrm{IC}_{50}$ value. Although the other inhibitors were not evaluated using microsomal preparations, it is likely that they may exhibit similar higher potencies.

\section{Effects of the RAMBAs alone and in combination with ATRA on LNCaP cell growth}

Given the retinoidal nature of our RAMBAs it seemed logical to investigate their effects on the growth of $\mathrm{LNCaP}$ cancer cells. The antiproliferative effect of ATRA was also studied for comparison using a WST assay. Continuous exposure of LNCaP cells to various doses of the RAMBAs and ATRA for 6 days led to dose-dependent inhibition of cell growth as shown in Figure 4 . The calculated $\mathrm{IC}_{50}$ values (defined as the concentration of compounds required to inhibit cell growth by $50 \%$ ) from these dose-response curves are presented in Table 1 and show that all RAMBAs are modest inhibitors $\left(\mathrm{IC}_{50}=4.5-10.0 \mu \mathrm{M}\right)$ of $\mathrm{LNCaP}$ cell proliferation and comparable to the potency of ATRA $\left(\mathrm{IC}_{50}=4.3 \mu \mathrm{M}\right)$.

The ability of each of these RAMBAs to enhance the antiproliferative activity of ATRA in LNCaP cells was also studied. ATRA inhibits LNCaP cell proliferation in a concentrationdependent manner (Figure 4) with a calculated $\mathrm{IC}_{50}$ value of $4.3 \mu \mathrm{M}$ (Table 1). For studies of effects of combination of RAMBAs with ATRA, we used low doses $(1 \mu \mathrm{m}$ each, doses that exhibited low $[<10 \%]$ antiproliferative effects) of RAMBAs. All RAMBAs, that is, VN/14-1, VN/50-1, VN/66-1, VN/69-1 each in combination with ATRA, significantly enhance the antiproliferative activity of ATRA, by 47-, 60-, 70-, 65-fold, respectively (for VN/14-1, $\mathrm{IC}_{50}$ from 10.0 to $0.092 \mu \mathrm{m}$; for $\mathrm{VN} / 50-1, \mathrm{IC}_{50}$ from 6.0 to $0.071 \mu \mathrm{M}$; for $\mathrm{VN} / 66-1$, $\mathrm{IC}_{50}$ from 4.5 to $0.061 \mu \mathrm{M}$; and for $\mathrm{VN} / 69-1, \mathrm{IC}_{50}$ from 5.0 to $0.066 \mu \mathrm{M}$ ) (Figure 4 and Table 1). These enhancements of ATRA activity are considered synergistic because the growth inhibitory effects were each significantly greater than the predicted values.

\section{Effects of the RAMBAs alone and in combination with ATRA on LNCaP cell differentiation}

Cytokeratins $8 / 18$ are present in the differentiated luminal epithelia in prostate and an increase in their content is considered to indicate differentiation (Owens and Lane, 2003). To determine the effects of these retinoids on cell differentiation, LNCaP cells were incubated with various concentrations of ATRA or RAMBA for 6 days; cell lysates were prepared and subjected to SDS-PAGE gel electrophoresis. Increase in cytokeratin 8/18 expression was used as the marker for differentiation (Peehl et al, 1993; Hsieh et al, 1995). There was a concentration-dependent increase in the expression of cytokeratin $8 / 18$ in LNCaP cells treated with ATRA, VN/14-1, VN/50-1, VN/66-1, and VN/69-1 (data not shown) and also a significant increase in the cytokeratin $8 / 18$ expression for 5 
A

Control

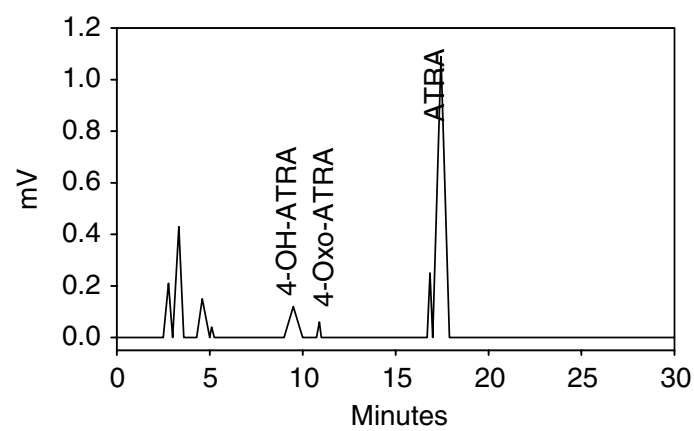

C

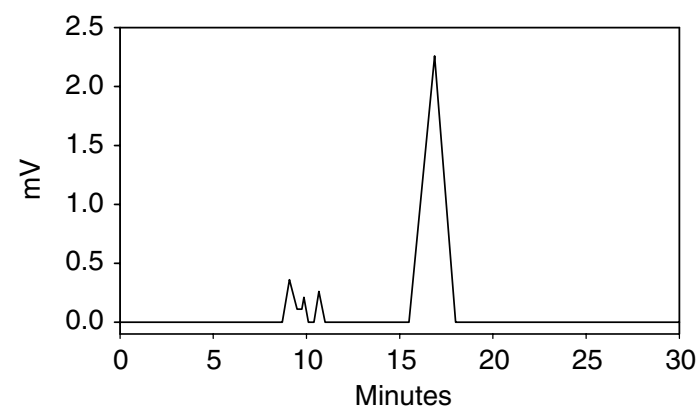

B

$0.1 \mathrm{~nm}$ VN/14-1

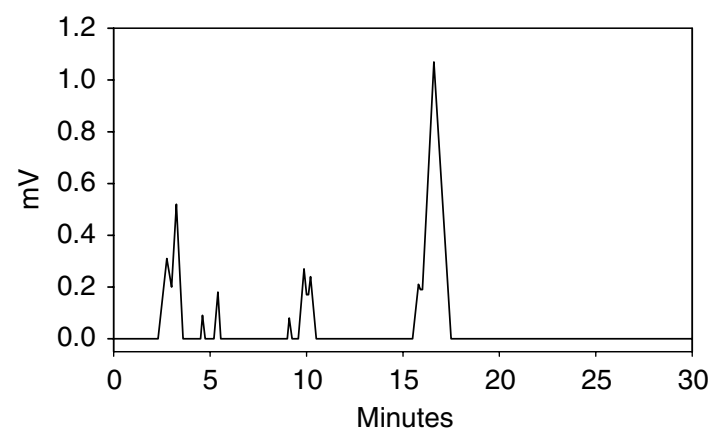

D

1000 nm VN/14-1

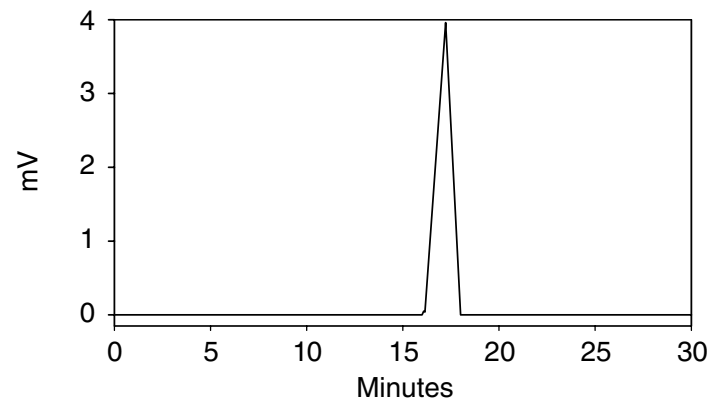

Figure 3 Inhibition of ATRA metabolism by VN/I4-I in intact LNCaP cells. Human LNCaP prostate cancer cells were cultured under basal conditions (data not shown) or pretreated with I $\mu$ M ATRA (A-D). Thereafter, cells were washed, and incubated with $0.1 \mu \mathrm{M}\left[1 \mathrm{I}, 12-{ }^{3} \mathrm{H}\right]$-ATRA, either in the absence (A) or presence (B-D) of VN/I4-I at concentrations of 0.1, I0, and I000 nM, respectively. The cells and media were collected, extracted and analysed by reverse phase HPLC as described in Materials and Methods. The experiments were performed twice.

Table I IC $C_{50}$ values of the RAMBAs on cellular CYP26 and LNCaP cell growth inhibition assays

\begin{tabular}{|c|c|c|c|c|}
\hline \multirow[b]{3}{*}{ Compound } & \multirow[b]{3}{*}{ 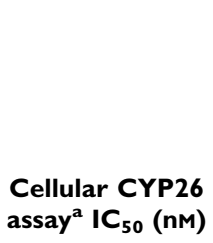 } & \multicolumn{3}{|c|}{ Cell growth inhibition ${ }^{b}$} \\
\hline & & \multirow{2}{*}{$\begin{array}{c}\begin{array}{c}\text { Agents } \\
\text { alone }\end{array} \\
\mathrm{IC}_{50}(\mu \mathrm{M})\end{array}$} & \multicolumn{2}{|c|}{$\begin{array}{l}\text { Combination } \\
\text { with RAMBAs }\end{array}$} \\
\hline & & & $\mathrm{IC}_{50}(\mu \mathrm{M})$ & $\begin{array}{c}\text { Fold } \\
\text { enhancement }\end{array}$ \\
\hline ATRA & - & 4.3 & - & \\
\hline VN/I4-I & $6.5 \pm 1.5$ & 10.0 & $0.092 *$ & +47 \\
\hline VN/50-I & $90.0 \pm 10.0$ & 6.0 & $0.07 \mid *$ & +60 \\
\hline VN/66-I & $62.5 \pm 12.5$ & 4.5 & $0.061 *$ & +70 \\
\hline VN/69-I & $90.0 \pm 12.5$ & 5.0 & $0.066 *$ & +65 \\
\hline
\end{tabular}

${ }^{a}$ The cellular CYP26 assay was performed using [1 1, 12- $\left.{ }^{3} \mathrm{H}\right]$-ATRA as a substrate for CYP26 with the addition of various concentrations of each RAMBA. The retinoids were extracted, processed, and analysed by HPLC. Percent metabolism vs the concentration of RAMBA used was obtained and graphed. $\mathrm{I}_{50}$ values were determined as the concentration of RAMBA that inhibited the metabolism of $\left[11,12-{ }^{3} \mathrm{H}\right]-\mathrm{ATRA}$ by $50 \%$. ${ }^{b}$ For cell growth inhibition studies, LNCaP cells were incubated with various concentrations of ATRA and the RAMBAs alone and in combination. The WST-I assay was performed. The plot represents the percentage of viable cells vs the concentration of RAMBA used. The I $\mathrm{I}_{50}$ value was determined as the concentration of RAMBA that inhibited LNCaP cell viability by $50 \% .{ }^{\circ} \mid \mu \mathrm{M}$ of each RAMBA was used. Statistical significance was defined at the level of $* P<0.05$.

and $10 \mu \mathrm{M}$ treatment for ATRA and all RAMBAs $(P<0.05)$ compared to control (data not shown). This increase in cytokeratin 8/18 expression in LNCaP cells treated with ATRA and the RAMBAs is indicative of differentiation.

For combination studies, LNCaP cells were incubated with $1 \mu \mathrm{M}$ ATRA, alone and in combination with $1 \mu \mathrm{M}$ of RAMBA for 6 days.

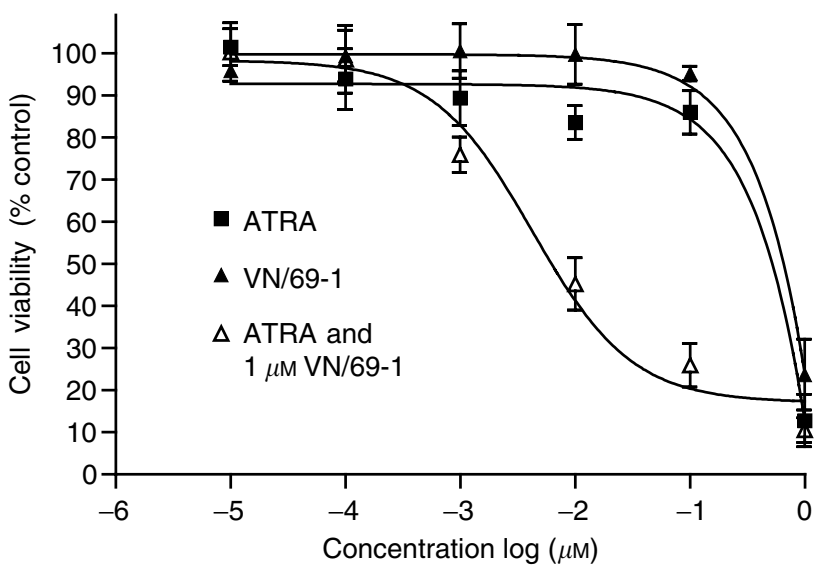

Figure 4 Antiproliferative effects of ATRA or VN/69-I alone and ATRA in combination with VN/69-I $(\mid \mu \mathrm{M})$. LNCaP cells were incubated with various concentrations of ATRA, the RAMBAs alone and in combination. The MTT assay was performed. The plot represents the percentage of viable cells vs the concentration of agents used. The $I C_{50}$ value was determined as the concentration of agents that inhibited the viability of LNCaP cells by $50 \%$. Similar results were obtained for VN/I4-I, VN/50-I, $\mathrm{VN} / 66-\mathrm{I}$, and 4-HPR.

Our results are summarised in Figure 5 and show significantly increase in the expression of cytokeratin $8 / 18$ by 1.18 to 1.38 -fold above control $(1 \pm 0.07, P<0.05)$. ATRA $(1 \mu \mathrm{M})$ in combination with $1 \mu \mathrm{M}$ of each of the RAMBAs, except for VN/69-1, also significantly increased the expression of cytokeratin $8 / 18$ by $1.32-$ 1.59 -folds above control [ $1 \pm 0.07,(P<0.05)]$. Thus, most RAMBAs 


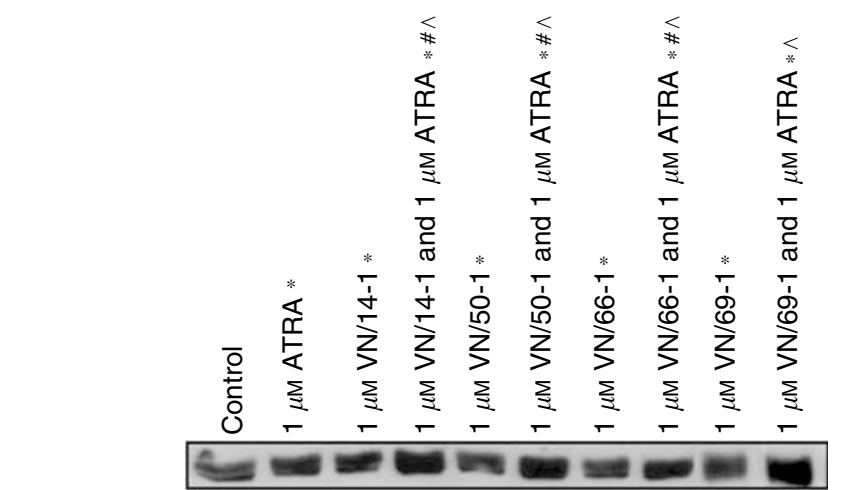

Fold over control

$\begin{array}{lllllllll}1.38 & 1.18 & 1.59 & 1.23 & 1.51 & 1.28 & 1.48 & 1.19 & 1.32\end{array}$

$\beta$-actin

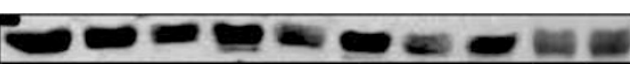

Figure 5 Effects of ATRA and RAMBAs alone and in combination on levels of cytokeratin 18 (a differentiation marker) in human prostate LNCaP cells. Cells were incubated with ATRA or RAMBAs alone or in combinations for 6 days. Lysates were subjected to SDS-PAGE and Western blotting. Membranes were probed with cytokeratin 18 antibody, and intensities of bands were analysed by densitometry. Groups labelled with * are significantly different from control $(P<0.05)$. Groups labelled with \# are significantly different from ATRA alone $(P<0.05)$. Groups labelled with ${ }^{\wedge}$ are significantly different between combination RAMBA with ATRA compared to the corresponding RAMBA alone $(P<0.05)$

enhanced the prodifferentiation activity of ATRA in the LNCaP cells.

TUNEL analysis of LNCaP cells treated with ATRA, 4-HPR, and RAMBAs

One of the possible mechanisms underlying the observed effect of ATRA and the RAMBAs on LNCaP cell viability is the direct induction of apoptosis. To test this hypothesis, TUNEL assays were performed following treatment of cells with the various agents. LNCaP cells treated with 1 or $5 \mu$ M ATRA, 4-HPR, or RAMBA for 6 days were processed for TUNEL staining, and viewed under fluorescence microscopy to examine the presence of nicked DNA that are hallmarks of apoptosis. Pictures obtained from the staining of control, ATRA, and VN/69-1 are shown in Figure 6A and results from the TUNEL analysis for all the test compounds are summarised in Figure 6B. Generally, there was a concentrationdependent induction of apoptosis in LNCaP cells treated with 1 or $5 \mu \mathrm{M}$ ATRA, 4-HPR, VN/14-1, VN/50-1, VN/66-1, and VN/69-1. Treatment with the most potent RAMBAs, VN/14-1 and VN/50-1 $(5 \mu \mathrm{M})$, yielded a percentage of apoptotic cells of 17.03 and $17.03 \%$, respectively (Figure 6B).

\section{Effects of ATRA, 4-HPR, and RAMBAs on expressions of Bad and Bcl-2}

Bcl-2 is an antiapoptotic protein and acts through inhibition of mitochondrial cytochrome $c$ release (Murphy et al, 2000). Bad is pro-apoptotic and acts by displacing Bax from binding to Bcl-2 (Yang et al, 1995; Zha et al, 1996). Bax then dissipates the mitochrondrial membrane releasing cytochrome $c$ which leads to apoptosis (Rosse et al, 1998). 4-HPR was used as a reference compound as it was well established to induce apoptosis (Fontana and Rishi, 2002). We observed a significant increase in Bad expression for 5 and $10 \mu \mathrm{m}$ treatment with ATRA and the RAMBAs compared with control $(P<0.05)$, with the exception of 4 -HPR, where all treatment concentrations of 4 -HPR $(0.1,1$ and $5 \mu \mathrm{M})$ were significant $(P<0.05)$ and VN/69-1, where treatments with 1,5 , and $10 \mu \mathrm{M}$ VN/69-1 were significant $(P<0.05)$ (Figure 7$)$. Our results
A

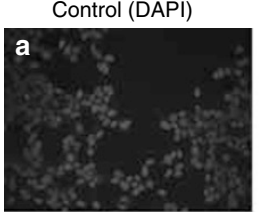

ATRA (DAPI)

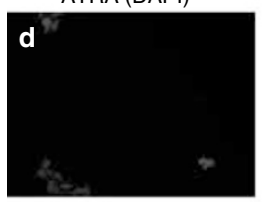

VN/69-1 (DAPI)

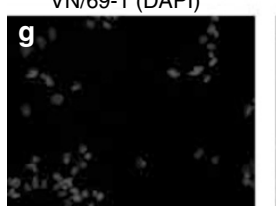

B

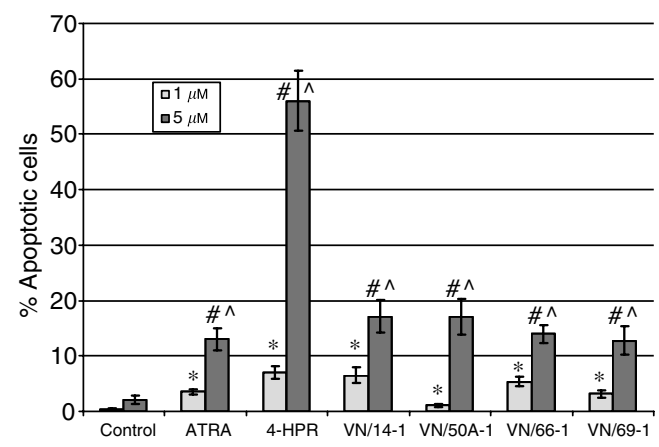

Figure 6 (A) Apoptosis in LNCaP cells determined by TUNEL and analysed by fluorescence microscopy. LNCaP cells were treated with $5 \mu \mathrm{M}$ ATRA or RAMBA for 6 days. Cells were then fixed, stained, mounted, and examined under fluorescence microscopy. Control is shown in $\mathbf{a}, \mathbf{b}$, and $\mathbf{c}$. ATRA $(5 \mu \mathrm{M})$ is shown in $\mathbf{d}$, e, and $\mathbf{f}$. VN/69-I (5 $\mu \mathrm{M})$ is shown in $\mathbf{g}, \mathbf{h}$, and $\mathbf{i}$. Nuclear DAPI staining is shown in $\mathbf{a}$, $\mathbf{d}$, and $\mathbf{g}$. FITC staining for nicked DNA is shown in $\mathbf{b}$, e, and $\mathbf{h}$. Combined DAPI and FITC staining is shown in $\mathbf{c}, \mathbf{f}$, and $\mathbf{i}$. (B) TUNEL analysis of LNCaP cells treated with ATRA, 4HPR, or RAMBAs. LNCaP cells were incubated with either I or $5 \mu \mathrm{M}$ of ATRA, 4-HPR, or a RAMBA for 6 days. LNCaP cells were then fixed, stained, mounted, and analysed by fluorescence microscopy. The number of apoptotic cells and total number of cells were counted in each of the five fields for each treatment and the percentage of apoptotic cells was calculated and plotted. Treatment with I $\mu \mathrm{M}$ drugs significantly increased from its control (*) $(P<0.05)$. Treatment with $5 \mu \mathrm{M}$ drugs significantly increased from its control $(\#)(P<0.05)$. Treatment with $5 \mu \mathrm{M}$ of drugs significantly increased from I $\mu \mathrm{M}$ of the same drug $(\wedge)(P<0.05)$

show that there was a concentration-dependent increase in Bad expression in LNCaP cells treated with all of the tested agents. Although there was a concentration-dependent decrease in the expression of Bcl-2 in LNCaP cells treated with ATRA and VN/141, treatments with 4-HPR, VN/50-1, VN/66-1, and VN/69-1, however, did not effect Bcl-2 expression (data not shown).

\section{Cell-cycle analysis of LNCaP cells treated with ATRA, 4- HPR, and RAMBAs}

Owing to the antiproliferative activities of these agents, it was of interest to determine their effects on cell-cycle distribution and apoptosis. LNCaP cells were treated with 1 or $5 \mu \mathrm{M}$ ATRA, 4-HPR, or RAMBA for 6 days. However, only the cell-cycle analysis of LNCaP cells treated with $5 \mu \mathrm{m}$ of the agents are shown in Figure 8 


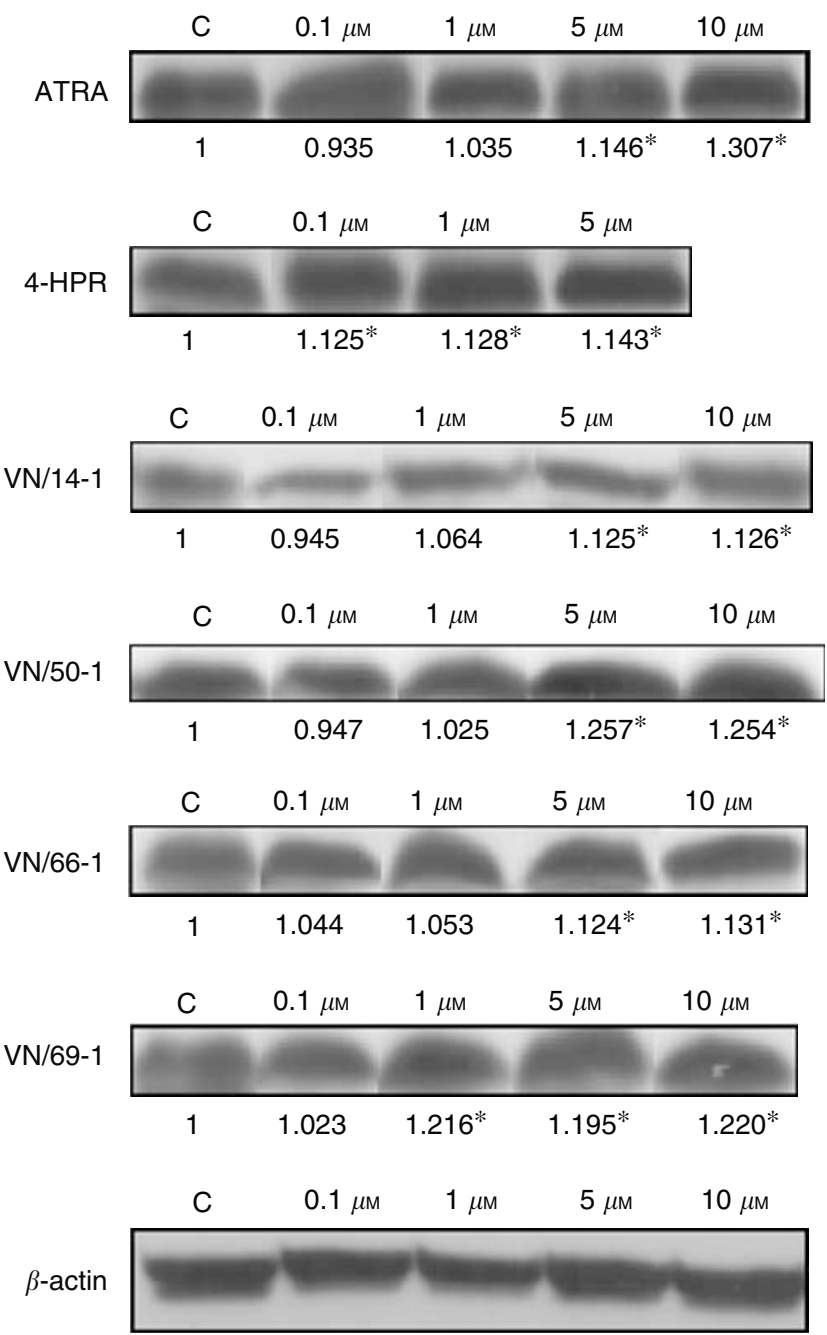

Figure 7 Western immunobloting of whole-cell lysates of treated LNCaP cells for expression of Bad. Cell lysates were used as described in the differentiation assay. Bad is a proapoptotic protein. The Western blots of Bad expressions are shown. The lanes are labelled above the blots and the expression of Bad is expressed as fold over control as determined by densitometry (below the blot). There was a significant difference in groups labelled with * compared to control $(P<0.05)$

and also summarised in Table 2. With these treatments, there was no change in the percentage of cells in the $G_{0} / G_{1}$ phase (except for ATRA treatment), a decrease in the percentage of cells in the $S$ phase, and an increase in the percentage of cells in the $G_{2} / M$ phase (a G2/M cell arrest, Table 2). There was also an increase in the percentage of cell in the sub-G1 phase that indicates apoptotsis in LNCaP cells treated with these agents.

\section{The effects of ATRA and RAMBAs in LNCaP xenograph SCID mouse model}

We next tested the effects of our RAMBAs on growth inhibition of LNCaP tumour xenographs. Male SCID mice bearing LNCaP tumour xenographs (approximately $100 \mathrm{~mm}^{3}$ ) were grouped and treated once daily with $0.033 \mathrm{mmol} \mathrm{kg}^{-1}$ each of ATRA or RAMBAs for the indicated time periods. As treatment with VN/50-1 was very toxic to the mice, experiment with this cohort was terminated. Tumour growth in the group receiving VN/14-1 was not significantly different from that observed in the vehicle control group (Figure 9). Mice receiving VN/66-1 or VN/69-1 had 44 and
$47 \%$, respectively, reduction in tumour growth compared to control $(P<0.05)$, whereas treatment with ATRA reduced tumour growth by $75 \%$ relative to control $(P<0.05)$ (Figure 9$)$. During the study, all mice were weighed twice a week. Whereas the body weights of mice in the RAMBAs-treated groups were not altered, weights of mice in the ATRA-treated group were significantly ( $\sim 25 \%)$ reduced compared to control (data not shown).

\section{DISCUSSIONS}

The prompt emergence of resistance to ATRA therapy in oncology and dermatology is a major concern in the development of ATRA (Miller, 1998; Njar, 2002, 2006). Agents that are able to inhibit ATRA metabolism may be used alone or in combination with low doses of ATRA or other therapeutic agents for the treatment of a variety of cancers and dermatological diseases. Interest in the development of structurally diverse agents as RAMBAs has increased over the last 5 years. We have developed several atypical RAMBAs with retinoidal scaffolds that possess unique multiple biological activities (Patel et al, 2004, 2006; Belosay et al, 2005; Njar, 2006). In this study, we have investigated the effects and mechanisms of action of several of these RAMBAs in human prostate LNCaP carcinoma cells.

Han and Choi (1996) were able to induce ATRA 4-hydroxylase in T47D cells and suggested that ATRA induces its own metabolism through a negative feedback mechanism. The enzyme activities induced by ATRA appear to be regulated at the level of transcription. Our results showed that only LNCaP cells were able to metabolise ATRA through induction of CYP26 (Figure 2). PC3 cells did not metabolise ATRA and the metabolism of ATRA did not exceed basal levels despite induction of CYP26 in DU145 cells. These results suggest that hormone-dependent cells (LNCaP) are able to metabolise ATRA following induction of CYP26 and that hormone-independent cells (PC3 and DU145) are not. To the best of our knowledge, this appears to be the first report of induction of ATRA 4-hydroxylase (CYP26) in LNCaP cells. The lack of ATRAinduced CYP26 in both PC3 and DU145 cells may be due to the loss of RARs in these cell lines. Several investigators have reported that the loss of RAR signaling in many epithelial tumours is driven by loss of expression of RARs (Campbell et al, 1998; Zhang, 2002).

Based on the $\mathrm{IC}_{50}$ values of the RAMBAs in hamster hepatic microsomes that were obtained previously (Patel et al, 2004), representative RAMBAs (VN/14-1, VN/50-1, VN/66-1, and VN/691) (Figure 1) were studied further in LNCaP cells. In intact LNCaP cells, these compounds potently inhibit ATRA metabolism (Figure $3 \mathrm{C}-\mathrm{D}$ and Table 1 ). The $\mathrm{IC}_{50}$ values obtained for VN/14-1, VN/661 , and VN/69-1 were comparable to the values seen in cellular MCF7 and T47D breast cancer cells that were determined previously (Patel et al, 2004). However, there was a discrepancy in the $\mathrm{IC}_{50}$ value for VN/50-1 (10.0 nM in T47D cells $v s 90.0 \mathrm{nM}$ in LNCaP cells). This difference may be due to the ability of VN/50-1 to penetrate the cell membranes of the LNCaP PCA cells. Similar results have recently been reported for farnesol derivatives that are weak inhibitors of ATRA metabolism in human head and neck squamous cell carcinoma (AMC-HN-6) cells and their microsomal preparations (Kim et al, 2001).

In $\mathrm{LNCaP}$ cell proliferation experiments, each of the RAMBAs tested enhanced the antiproliferative activity of ATRA (Figure 4 and Table 1). The antiproliferative effects of ATRA was enhanced by 47 - to 70 -fold with the addition of $1 \mu \mathrm{M}$ VN/14-1, VN/50-1, VN/ 66-1, or VN/69-1. Concentrations of RAMBAs effective in enhancing the antiproliferative activity of ATRA are themselves unable to significantly decrease LNCaP cell proliferation. Thus, these data support the hypothesis that our compounds enhance the biological activity of ATRA through inhibition of ATRA metabolism. These results are identical with those previously observed in human breast MCF-7 cancer cells (Patel et al, 2004), but are 

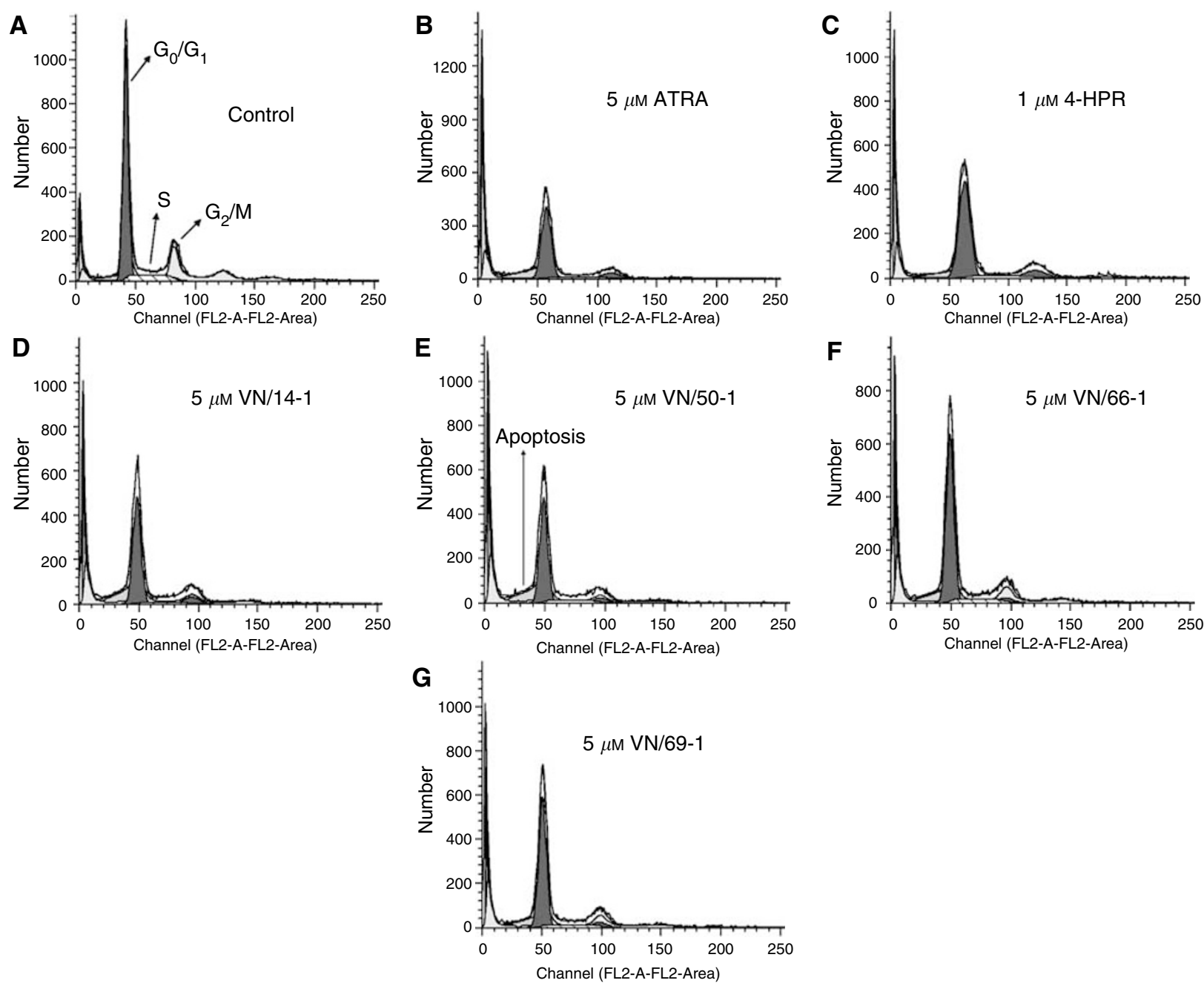

Figure 8 Cell-cycle analysis of LNCaP cells treated with I or $5 \mu \mathrm{M}$ ATRA, 4-HPR or RAMBAs. LNCaP cells were incubated with either I or $5 \mu \mathrm{M}$ ATRA, 4-HPR, or RAMBA for 6 days. LNCaP cells were then fixed, stained with propidium iodide, and analysed by FACScan. Histograms of the FACScan analysis from control (A), ATRA (B), 4-HPR (C), VN/I4-I (D), VN/50A-I (E), VN/66-I (F), and VN/69-I (G) are shown.

Table 2 Cell-cycle analysis of LNCaP cells treated with I or $5 \mu \mathrm{M}$ ATRA 4-HPR or RAMBAs

\begin{tabular}{lcccc}
\hline Treatment & $\mathbf{G}_{\mathbf{0}} / \mathbf{G I}(\%)$ & $\mathbf{S}(\%)$ & G2/M (\%) & Sub-G I (\%) \\
\hline Control & 82.78 & 15.01 & 2.20 & 9.02 \\
ATRA $(5 \mu \mathrm{M})$ & 77.74 & 9.84 & 12.42 & 13.64 \\
$4-H P R(\mid \mu \mathrm{M})^{\mathrm{a}}$ & 79.53 & 9.18 & 12.03 & 7.52 \\
VN/I4-I $(5 \mu \mathrm{M})$ & 82.59 & 7.26 & 10.15 & 17.88 \\
VN/50-I $(5 \mu \mathrm{M})$ & 81.33 & 11.38 & 7.30 & 17.67 \\
VN/66-I $(5 \mu \mathrm{M})$ & 83.80 & 11.14 & 5.07 & 14.49 \\
VN/69-I $(5 \mu \mathrm{M})$ & 82.66 & 11.14 & 6.20 & 13.39 \\
\hline
\end{tabular}

LNCaP cells were incubated with either I or $5 \mu$ M ATRA, 4-HPR, or RAMBA for 6 days. LNCaP cells were then fixed and stained with propidium iodide. $10^{4} \mathrm{LNCaP}$ cells were analysed by FACScan. The percentages of cells in the $G_{0} / G_{1}, S$, and $G_{2} / M$ were calculated from diploid cells. The percentage of apoptotic cells (sub $G_{0} / G_{1}$ ) was calculated from the total number of cells minus the debris. The percentages of cells in $G_{0} / G_{1}, S$, and $G_{2} / M$ phases of the cell cycle as well as percentage of apoptotic cells (sub-G ) were determined using MODFIT LT software. ${ }^{a}$ Treatment with $5 \mu \mathrm{M} 4-\mathrm{HPR}$ resulted in a massive amount of cell death such that no cell-cycle analysis could be performed.

superior to the effects observed with R116010 in human breast T47D cancer cells (Van Heusden et al, 2002). In the latter study, $\mathrm{R} 116010$, at a concentration of $1 \mu \mathrm{M}$, enhanced the antiproliferative activity of ATRA only by threefold. As expected, our RAMBAs also inhibited the growth of LNCaP cells in a dose-dependent manner, with $\mathrm{IC}_{50}$ values ranging from 4.3 to $10 \mu \mathrm{M}$ (Figure 4 and Table 1), which correlates with their intrinsic retinoidal antiproliferative activities.

Having established the in vitro antiproliferative activities of these novel compounds alone and in combination with ATRA, we set out to investigate possible molecular mechanisms that might be involved using established procedures. On the basis of our previous studies and knowledge that these RAMBAs possess both intrinsic retinoid-like activities and also ATRA-mimetic effects (Patel et al, 2004), we assessed their effects on cell differentiation, apoptosis and cell cycle.

Indeed, this study presents evidence that our RAMBAs induce differentiation (via upregulation of cytokeratin $8 / 18$ expression) and also significantly enhance ATRA-induced differentiation in the LNCaP cells. We have previously shown that with the exception of VN/14-1, the other three RAMBAs were weak ligands and activators of the RAR $\alpha$. As it is believed that only ligands that activate RAR $\alpha$ induce cell differentiation (Bollag et al, 1997), the present data suggest that induction of differentiation can also occur via RAR $\alpha$-independent pathway. The ability of the RAMBAs to enhance ATRA-induced differentiation may be attributed to intracellular inhibition of ATRA metabolism with concomitant accumulation of cellular ATRA. 


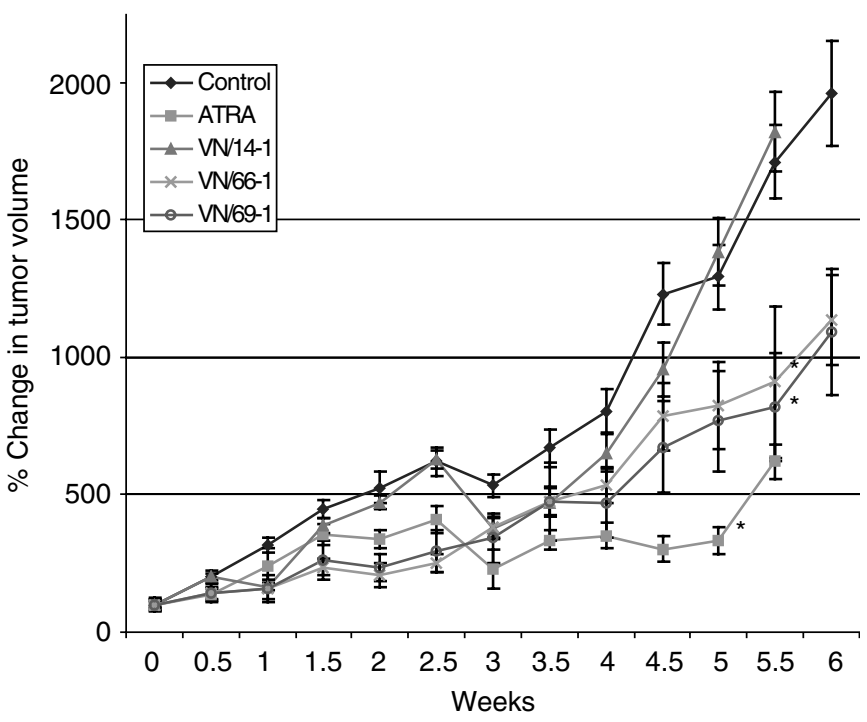

Figure 9 The effect of ATRA, VN/I4-I, VN/66-I on LNCaP tumour volumes in male SCID mice. Male SCID mice were inoculated S.C. with LNCaP cells suspended in Matrigel at two sites in the flank. The sizes of the tumours were determined by measuring the tumour volumes using calipers. Tumour volumes were calculated using the formula $V=4 / 3 \times \pi \times r_{1}^{2} \times r_{2}$ $\left(r_{1}<r_{2}\right)$. The tumours were allowed to develop to $100 \mathrm{~mm}^{3}$ before treatment. The mice were treated with an equivalent dose to $0.033 \mathrm{mmol} \mathrm{kg}{ }^{-1}$ of ATRA, VN/I4-I, VN/66-I or VN/69-I. The vehicle control was hydroxypropyl- $\beta$-cyclodextrin (HPC) in saline. (*) indicated that these treatment groups were significantly different from vehicle control $(P<0.05)$

In the normal prostate, there is a balance between cell proliferation and cell death (Denmeade et al, 1996), while in PCA, the proliferative rate remains relatively low, but there is less apoptosis (Berges et al, 1995). Our results here demonstrate that RAMBAs were able to induce apoptosis in LNCaP cells as determined by the TUNEL assay. Induction of apoptosis appears to be associated with upregulation of the proapoptotic protein Bad and reduction or no change in the levels of antiapoptotic Bcl-2. Furthermore, cell-cycle analysis revealed that these agents significantly induce arrest of cell in the $\mathrm{G}_{2} / \mathrm{M}$ phase. It should be stated that there is a major checkpoint in the $\mathrm{G}_{2} / \mathrm{M}$ phase of the cell cycle where cells arrested in the $\mathrm{G}_{2} / \mathrm{M}$ phase can undergo apoptosis if optimal conditions are not met (Kastan and Bartek, 2004). This scenario may also be operational in this study. Therefore, our findings that our RAMBAs cause $\mathrm{G}_{2} / \mathrm{M}$ arrest and induce apoptosis in the LNCaP cells offer a potential new therapeutic option for PCA therapy.

The marked effects that our RAMBAs had on cell proliferation led to in vivo studies. Our in vivo studies showed that VN/14-1 was ineffective in this model as it did not cause inhibition of tumour growth (Figure 9). VN/50-1 was toxic to the animals and its antitumour efficacy could not be assessed. The lack of antitumour efficacy of VN/14-1 in the LNCaP PCA model is rather puzzelling because the compound has been shown to possess excellent antitumour efficacy in the MCF-7 human breast cancer model (Patel et al, 2004, 2006). Clearly, more studies are required to explain this unexpected finding. In contrast to the effects of VN/ 14-1, the other two RAMBAs, VN/66-1 and VN/69-1 as well as ATRA exhibited statistically significantly LNCaP tumour growth inhibition. Despite the fact that ATRA exhibited a more potent antitumour activity, the significant decrease (25\%) in body weights of animals in this cohort is indicative of toxicity, which is a matter of concern. Although a first generation RAMBA, liarozole has been shown to exhibit potent antitumour efficacy against human androgen-independent PCA tumours, such as PC-3ML-B (Stearns et al, 1993), and DU-145 (Smets et al, 1994) and several rat PCA tumours (De Coster et al, 1992; Dijkman et al, 1994); this study appears to be the first report on the antitumour efficacy of RAMBAs against human androgen-dependent LNCaP PCA tumours. Recently, it was demonstrated that a second generation RAMBA, R116010, was able to significantly inhibit the growth of murine TA3-Ha mammary tumours in A/J mice (Van Heusden et al, 2002). Given that our RAMBAs exhibited potent in vitro antiproliferative activities, their in vivo antitumour efficacies are rather disappointing. The reason(s) for these discrepancies are unknown at this time but could be caused by the rapid metabolism of the various RAMBAs to inactive metabolites in vivo or the combined effects of RAMBAs and endogenous constituents that, in combination with the RAMBAs exert poor inhibitory effects on tumour growth. Clearly, further in vivo studies using other doses of the RAMBAs and modes of administrations are necessary to determine fully the usefulness of these novel compounds in PCA.

In conclusion, we have identified potent inhibitors of ATRA metabolism in intact human LNCaP PCA cells. Inhibition of ATRA metabolism leads to enhanced antiproliferative activity of ATRA both in vitro and in vivo. This report, to our best knowledge, is the first to demonstrate the induction of cell differentiation, apoptosis and $\mathrm{G}_{2} / \mathrm{M}$ cell cycle arrest by RAMBAs in human PCA cells. Our findings suggest that additional studies to determine the efficacy of our novel RAMBAs in the treatment of human prostate cancer are warranted.

\section{ACKNOWLEDGEMENTS}

This research was supported by grants from the U.S. Department of Defense under the Peer Review Medical Research Program (W81XWH-04-1-0101), the U.S. Army Medical Research and Material Command (DAM D17-01-1549), TEDCO and National Institutes of Health (R21 CA117991-01) to V.C.O.N. We thank all these agencies for their generous support.

\section{REFERENCES}

Belosay A, Njar VCO, Brodie AMH (2005) Effects and molecular mechanisms of novel retinoic acid metabolism blocking agent (VN/141) in MCF-7Ca cells insensitive to aromatase inhibitor letrozole. Clin Cancer Res (in review)

Berges RS, Vukanovic J, Epstein JI, Carmichel M, Cisek L, Johnson DE, Veltri RW, Walsh PH, Isaacs JT (1995) Implications of cell kinetic changes during progression of human prostatic cancer. Clin Cancer Res 1: 475-481

Bollag W, Isnardi L, Jablonski S, Klaus M, Majewski S, Pirson W, Toma S (1997) Links between pharmacological properties of retinoids and nuclear retinoid receptors. Int J Cancer 70: 470-472

Campbell MJ, Park S, Uskokovic MR, Dowson MI, Koeffler HP (1998) Expression of retinoic acid receptor-beta sensitizes prostate cancer cells to growth inhibition mediated by combinations with retinoids and a 19nor hexafluoride vitamin D3 analog. Endocrinology 139: 1927-1980

Carter BS, Carter B, Issacs JT (1990) Epidemiological evidence regarding predisposing factors to prostate cancer. Prostate 16: 187-197

Chambon P, Zelent A, Petkovick M, Mendelsohm C, Leroy R, Krust A, Kastner P, Brand N (1991) The family of retinoic acid nuclear receptors. In Retinoids: 10 Years On, Saurat JH (ed) pp 10-27. Switzerland: Karger

De coster R, Wouters W, Van Ginckel R, End D, Krekels M, Coene M-C, Bowden C (1992) Experimental studies with liarozole (R 75251): an antitumoral agent which inhibits retinoic acid breakdown. J Steroid Biochem Molec Biol 43: 197-201 
De Luca LM, Darwiche N, Jones CS, Scita G (1995) Retinoids in differentiation and neoplasia. Sci Am 2: 28-37

Denmeade SR, Lin XS, Isaacs JT (1996) Role of programmed (apoptoic) cell death during the progression and therapy for prostate cancer. Prostate 28: $2516-2522$

Dijkman GA, Van Moorselaar RJA, Van Ginkel R, Van Stratum P, Wouters L, Debruyne FMJ, Schalken JA, De Coster R (1994) Antitumoral effects of liarozole in androgen-dependent and androgen-independent R3327Dunning prostate adenocarcinomas. J Urol 151: 217-222

Fontana JA, Rishi AK (2002) Classical and novel retinoids: their targets in cancer therapy. Leukemia 16: $463-472$

Frolik CA, Roberts AB, Travala TE, Roller P, Newton DL, Sporn MB (1979) Isolation and identification of 4-hydroxy- and 4-oxoretinoic acid. In vitro metabolites of all-trans-retinoic acid in hamster trachea and liver. Biochemistry 18: $2092-2097$

Gao M, Ossowski L, Ferrari AC (1999) Activation of Rb and decline in androgen receptor protein precede retinoic acid-induced apoptosis in androgen-dependent $\mathrm{LNCaP}$ cells and their androgen-independent derivatives. J Cell Physio 179: 336-346

Grigoryev DN, Long BJ, Njar VCO, Liu Y, Nnane IP, Brodie AMH (1999) Effects of new $17 \alpha$-hydroxylase/C 17,20 -lyase inhibitors on LNCaP prostate cancer cell growth in vitro and in vivo. $\mathrm{Br} J$ Cancer 81: $622-630$

Han IS, Choi JH (1996) Highly specific cytochrome P450-like enzymes for all-trans-retinoic acid in T47D human breast cancer cells. J Clin Endocrinol Metab 81: 2069-2075

Hanchette CL, Schwartz GG (1992) Geographic patterns of prostate cancer mortality. Evidence for a protective effect of ultraviolet radiation. Cancer 70: $2861-2869$

Hayes RB, Bogdanovicz JF, Schroeder FH, De Bruijn A, Raatgever JW, Van der Maas PJ, Oishi K, Yoshida O (1988) Serum retinol and prostate cancer. Cancer 62: $2021-2026$

Hsieh TC, Xu W, Chiao JW (1995) Growth regulation and cellular changes during differentiation of human prostatic cancer LNCaP cells as induced by $\mathrm{T}$ lymphocyte-conditioned medium. Expt Cell Res 218: $137-143$

Huang ME, Ye YC, Chen SR, Chai JR, Lu JX, Jhoa L, Gu LJ, Wang ZY (1988) Use of all-trans-retinoic acid in the treatment of acute promyelocytic leukemia. Blood 72: $567-572$

Kastan MB, Bartek J (2004) Cell-cycle checkpoints and cancer. Nature 432: $316-323$

Kim SY, Kim C, Han IS, Lee SC, Kim SH, Lee K, Choi Y, Byun Y (2001) Inhibition effect of new farnesol derivatives on all-trans-retinoic acid metabolism. Metabolism 50: $1356-1360$

Lasnitzki I, Goodman DS (1974) Inhibition of the effects of methylcholoanthrene on mouse prostate in organ culture by vitamin A and its analogs. Cancer Res 34: $1564-1571$

Lippman SM, Benner SE, Houg WK (1994) Cancer chemoprevention. J Clin Oncol 12: $851-873$

Lotan R (1996) Retinoids in cancer chemoprevention. FASEB J 10: 1031 1039

Mangelsdorf DJ, Umesono K, Evans RM (1994) The retinoid receptors. In The Retinoids: Biology, Chemistry and Medicine, Sporn MB, Roberts AB, Goodman DS (eds), 2nd edn, pp 319-350. New York: Raven Press

Marill J, Idres N, Capron CC, Nguyen E, Chabot GG (2003) Retinoic acid metabolism and mechanism of action: a review. Curr Drug Metab 4: $1-10$

McDonnell TJ, Navone MN, Troncos P, Pisters LL, Conti C, von Eschenbach AC, Brisbay S, Logothetis CJ (1997) Expression of bcl-2 oncoprotein and p53 protein accumulation in bone marrow metastasis of androgenindependent prostate cancer. J Urol 157: 569-574

McDonnell TJ, Troncoso P, Brisbay SM, Logothetis C, Chung LW, Hsieh JT, Tu SM, Campbell ML (1992) Expression of protooncogene bcl-2 in the prostate and its association with the emergence of androgen-independent prostate cancer. Cancer Res 52: 5940-5944

Miller Jr WH (1998) The emerging role of retinoids and retinoic acid metabolism blocking agents in the treatment of cancer. Cancer 83: 1471 1482

Moon RC, Mehta RG, Rao KVN (1994) Retinoids and cancer in experimental animals. In The Retinoids: Biology, Chemistry and Medicine, Sporn MB, Roberts AB, Goodman DS (eds), 2nd edn, pp 573-595. New York: Raven Press

Muindi J, Frankel SR, Miller Jr WH, Jakubowski A, Scheinberg DA, Young CW, Dmitrovsky E, Warrell Jr RP (1992) Continuous treatment with alltrans-retinoic acid causes a progressive reduction in plasma drug concentrations: Implications for relapse and retinoid 'resistance' in patients with acute promyelocytic leukemia. Blood 79: 299-303

Murphy KM, Ranganathan V, Farnsworth ML, Kavallaris M, Lock RB (2000) Bcl-2 inhibits Bax translocation from cytosol to mitochondria during drug-induced apoptosis of human tumor cells. Cell Death Differ 7: $102-111$

Nagy L, Thomazy VA, Heyman RA, Chandraratna RAS, Davies PTA (1996) Retinoid-regulated expression of $\mathrm{Bcl}-2$ and tissue transglutaminase during differentiation and apoptosis of human myeloid leukemia (HL60) cells. Leuk Res 19: 499-505

Njar VCO (2002) Cytochrome P450 retinoic acid 4-hydroxylase inhibitors: Potential agents for cancer therapy. Mini Rev Med Chem 2: 261-269

Njar VCO, Gediya LK, Purushottamachar P, Chopra P, Huynh C, Belosay A, Patel JB (2006) Retinoic acid metabolism blocking agents (RAMBAs) for treatment of cancers and dermatological diseases. Bioorg Med Chem (in review)

Njar VCO, Nnane IP, Brodie AMH (2000) Potent inhibition of retinoic acid metabolism enzyme(s) by novel azolyl retinoids. Bioorg Med Chem Let 10: $1905-1908$

Norum KR (1993) Acute myeloid leukemia and retinoids. Eur J Clin Nutri 47: $77-87$

Owens DW, Lane EB (2003) The quest for the function of simple epithelial keratins. BioEssays 25: $748-758$

Pasquali D, Thaller C, Eichelle G (1996) Abnormal levels of retinoic acid in prostate cancer tissues. J Clin Endocrinol Metab 81: 2186-2191

Patel JB, Brodie AMH, Njar VCO (2006) Novel retinoic acid metabolism blocking agents (RAMBAs) have potent inhibitory activities on human breast cancer cells and tumor growth. Clin Cancer Res (in review)

Patel JB, Huynh CK, Handratta VD, Gediya LK, Brodie AMH, Goloubeva OG, Clement OO, Nanne IP, Soprano DR, Njar VCO (2004) Novel retinoic acid metabolism blocking agents endowed with multiple biological activities are efficient growth inhibitors of human breast and prostate cancer cells in vitro and a human breast tumor xenograft in nude mice. J Med Chem 47: 6716-6729

Peehl DM, Wong ST, Stamey TA (1993) Vitamin A regulates proliferation and differentiation of human prostatic epithelial cells. Prostate 23 $69-78$

Pienta KJ, Nguyet M, Lehr JE (1993) Treatment of prostate cancer in the rat with synthetic retinoid fenretinide. Cancer Res 53: 224-226

Pollard M, Luckert PH (1991) The inhibitory effects of 4-hydoxyphenyl retinamide (4-HPR) on metastasis of prostate adenocarcinoma-III cells in Lobund-Wistar rats. Cancer Lett 59: 159-163

Raffo AJ, Pelman H, Chen MW, Day ML, Streitman JS, Buttyan R (1995) Overexpression of bcl-2 protects prostate cancer cells from apoptosis in vitro and confers resistance to androgen depletion in vivo. Cancer Res 55: $4438-4445$

Reichman ME, Hayes RB, Ziegler RG, Schatzkin A, Taylor PR, Kahel, LL, Fraumein Jr JF (1990) Serum vitamin A and subsequent development of prostate cancer in the first National Health and Nutrition Survey. Epidemiologic follow-up study. Cancer Res 50: 2311-2315

Rosse T, Olivier R, Monney L, Rager M, Conus S, Fellay I, Jansen B, Borner C (1998) Bcl-2 prolongs cell survival after Bax-induced release of cytochrome $c$. Nature 391: 496-499

Smets G, Van-Gincle R, Xhonneux B, Borgers M, Van-husden J (1994) Antitumoral effects of liarozole on the growth of transplantable human DU145 prostatic carcinoma in athymic mice. Eur Soc Urol Oncol Endocrinol (abstract 96)

Smith MA, Adamson PC, Balis FM, Feusner J, Aronson L, Murphy RF, Horowitz ME, Reaman G, Hammond GD, Fenton RM (1992b) Phase and pharmacokinetic evaluation of all-trans-retinoic acid in pediatric patients with cancer. J Clin Oncol 10: $1666-1673$

Smith MA, Parkinson DR, Cheson BD, Friedman MA (1992a) Retinoids in cancer chemotherapy. J Clin Oncol 10: 839-864

Sporn MB (1991) Carcinogenesis and cancer: different perspectives on the same disease. Cancer Res 51: 6215-6218

Sporn MB, Dunlop NM, Newton DL, Smith JM (1976) Prevention of chemical carcinogenesis by vitamin A and its synthetic analogs (retinoids). Fed Proc 35: $1332-1338$

Sporn MB, Roberts AB, Goodman DS (eds) (1994) In The Retinoids: Biology Chemistry and Medicine, 2nd edn. New York: Raven Press

Stearns ME, Wang M, Fudge K (1993) Liarozole and 13-cis-retinoic acid anti-prostatic activity. Cancer Res 53: 3073 - 3077

Van Heusden J, Van Ginckel R, Bruwiere H, Moelans P, Janssen B, Floren W, Van der Leede BJ, Van Dun J, Sanz G, Venet M, Dillen L, Van Hove C, Willemsens G, Janicot M, Wouters W (2002) Inhibition of 
all-trans-retinoic acid metabolism by R116010 induces antitumor activity. Br J Cancer 86: 605-611

Wouters W (1994) Retinoid metabolism and its inhibition by liarozole fumarate. Ann Oncol 5(Suppl. 9): S45-S47

Wouters W, van Dun J, Dillen A, Coene MC, Cools W, De Coster R (1992) Effects of liarozole, a new antitumoral compound, on retinoic acid-induced inhibition of cell growth and on retinoic acid metabolism in MCF-7 human breast cancer cells. Cancer Res 52: $2841-2846$

Wu JM, DiPietrantonio AM, Hsieh T-C (2001) Mechanism of fenretinide (4-HPR)-induced cell death. Apoptosis 6: $377-388$
Yang E, Zha J, Jockel J, Boise LH, Thompson CB, Korsmeyer SJ (1995) Bad, a heterodimeric partner for $\mathrm{Bcl}-\mathrm{xL}$ and $\mathrm{Bcl}-2$, displaces $\mathrm{Bax}$ and promotes cell death. Cell 80: $285-291$

Young CYF, Murtha P, Andrews PE, Lindzey JK, Tindall DJ (1994) Antagonism of androgen action in prostate tumor cells by retinoic acid. Prostate 25: 39-45

Zha J, Harada H, Yang E, Jockel J, Korsmeyer SJ (1996) Serine phosphorylation of death agonist BAD in response to survival factor results in binding to 14-3-3 not Bcl-xL. Cell 87: 619-628

Zhang XK (2002) Vitamin A and apoptosis in prostate cancer. Endocr Relat Cancer 9: $87-102$ 